\section{Criminal Litigation}

Moira C. Dux

US Department of Veteran Affairs, Baltimore, MD, USA

\section{Definition}

In civil litigation, a lawsuit is filed by a private party, seeking damages from another party as a result of some type of injury, negligence, or malpractice. In criminal litigation, the case is filed by the government against a defendant whom the government believes has committed a crime. Crimes are classified into one of two categories: misdemeanors or felonies. Punishment for misdemeanors involve a maximum possible sentence of less than 1 year of incarceration; felonies carry a maximum possible sentence of more than 1 year of incarceration. The burden of proof in criminal litigation is always assumed by the state. Thus, it is the state's responsibility to prove that the defendant is guilty of having committed a crime. However, if a defendant claims insanity (e.g., cannot appreciate the wrongfulness of the act nor conform their conduct to the requirements of the law), then the burden of proof in proving one's insanity falls on the defendant. Under criminal litigation, the state must demonstrate that the accused satisfied each element of the statutory definition of the crime and prove the defendant's involvement beyond a reasonable doubt. In the context of criminal litigation, forensic neuropsychologists often provide determinations regarding "mens rea" (e.g., guilty mind) or not guilty by reason of insanity (NGRI), competent waiver of Miranda rights, and/or competence to proceed (e.g., stand trial, to be sentenced, etc.).

\section{Cross-References}

Actus Rea

- Criminal Forensics

$>$ Insanity

Mens Rea

\section{References and Readings}

Denney, R. L., \& Sullivan, J. P. (2008). Clinical neuropsychology in the criminal forensic setting. New York: Guilford.

Greiffenstein, M. F., \& Cohen, L. (2005). Neuropsychology and the law: Principles of productive attorneyneuropsychologist relations. In G. Larrabee (Ed.), Forensic neuropsychology: A scientific approach. New York: Oxford University Press. 